\title{
Comparative analysis of electricity cogeneration scenarios in sugarcane production by LCA
}

\author{
João Paulo Macedo Guerra • José Roberto Coleta Jr. • \\ Luiza Carvalho Martins Arruda • Gil Anderi Silva • \\ Luiz Kulay
}

Received: 25 June 2013 / Accepted: 8 January 2014 / Published online: 28 January 2014

(C) The Author(s) 2014. This article is published with open access at Springerlink.com

\begin{abstract}
Purpose The decentralization of the Brazilian electricity sector in association with the internal electricity supply crisis has encouraged companies in the sugarcane industry to produce electricity by burning sugarcane bagasse in cogeneration plants. This approach reduces the environmental impact of the sugarcane production and has opened up opportunities for distilleries and annex plants to increase their product portfolios. Potential scenarios for technically and environmentally improving the cogeneration performance were analyzed by using thermodynamic analysis and Life Cycle Assessment (LCA).

Methods The method used in this study aimed to provide an understanding and a model of the electrical and thermal energy production and the environmental impacts of conventional vapor power systems which operate with a Rankine cycle that are commonly used by Brazilian distilleries. Vapor power system experts have suggested focusing on the following technical improvement areas: increasing the properties of the steam from 67 bar and $480{ }^{\circ} \mathrm{C}$ to 100 bar and $520^{\circ} \mathrm{C}$, regeneration, and reheating. Eight case scenarios were projected based on different combinations of these conditions. A functional unit of "To the delivery of $1.0 \mathrm{MWh}$ of electricity to the power grid from a cogeneration system" was defined. The
\end{abstract}

Responsible editor: Roland Hischier

J. P. M. Guerra • J. R. Coleta Jr. ․ C. M. Arruda • G. A. Silva • L. Kulay $(\bowtie)$

Chemical Engineering Department, Polytechnic School of the

University of Sao Paulo, Av. Prof. Lineu Prestes, 580, Bloco

18 - Conjunto das Químicas, 05424-970 São Paulo, Sao Paulo, Brazil

e-mail: luiz.kulay@usp.br

L. Kulay

e-mail: luiz.kulay@poli.usp.br product system covers the environmental burdens of the industrial stage and the agricultural production of sugarcane. Results and discussion Technical evaluation indicated that the energy efficiency improves as the pressure at which the vapor leaves the boiler increases. Simultaneously, the net power exported to the grid increases and the makeup water consumption in the cooling tower and the makeup water supplied to the boiler reduce. From the LCA, it was noted that the improved energy performance of the system is accompanied by reduced environmental impacts for all evaluated categories. In addition, vapor production at $100 \mathrm{bar}$ and $520^{\circ} \mathrm{C}$ results in greater environmental gains, both in absolute and relative terms.

Conclusions Reheating and regeneration concepts were found to be considerably effective in improving the energy and environmental performance of cogeneration systems by burning sugarcane bagasse. For the evaluated categories, the results indicate that the proposed modifications are favorable for increasing the efficiency of the thermodynamic cycle and for decreasing the environmental impacts of the product system.

Keywords Cogeneration · Energy efficiency $\cdot$ Life cycle assessment $\cdot$ Rankine cycle $\cdot$ Sugarcane industry

\section{Introduction}

Approximately four decades ago, discussions began throughout the world regarding the incorporation of renewable assets into the energy matrix, whether due to the economic instability of crude oil and an increasing rate of fossil resource depletion or the resulting environmental effects. Thus, it was starting a new environmental culture, in which industrial processes were carried out without concerning about the environmental impact (Gil et al. 2013). At present, the use of cleaner energy sources has become a crucial issue for modern society (Gonzáles-García et al. 2012; Luo et al. 2008). 
The current energy supply problems in association with the climate change awareness have been motivating the academy to look for renewable fuels and energy sources and put more efforts on studying its process energy efficiency and environmental impacts. Life Cycle Assessment (LCA) has been used more abundantly to assess the environmental impacts of process modifications (Gaudreault et al. 2010). In the past few years, several authors have addressed the thermodynamic analysis of renewable fuels, and others have addressed its environmental performance. Researchers, like Cavalett et al. (2013), have addressed the issue by doing a comparative LCA of ethanol versus gasoline in Brazil using different Life Cycle Impact Assessment (LCIA) methods, concluding that the use of different LCIA methods leads to different conclusions. In the particular case of ethanol and cogeneration plants, Ometto et al. (2009) has performed an LCA of fuel ethanol from sugarcane in Brazil, showing that the fuel ethanol life cycle contributes negatively to all impact potentials analyzed, but in terms of energy consumption, it consumes less energy than its own production largely because of the electricity cogeneration system. Nguyen and Gheewala (2008) have done an LCA of fuel ethanol from cane molasses in Thailand, concluding that the LCA helps to identify the key areas in the ethanol production to improve environmental performance. Renouf et al. (2011) generated an attributional LCA for products produced from Australian sugarcane, showing that the sugarcane products are influenced by some factors, like the nature of a caneprocessing system, the variability in sugarcane growing, etc.

Within the Brazilian scenario, the energy industry has one of the highest participation rates of renewable energy on the planet. In 2010, the contributions of hydroelectricity, biomass (using wood and charcoal), biofuels, and wind energy totaled $45.3 \%$ of the country's energy production (MME 2011). Within this context, participation from the sugarcane industry is important because Brazil is the world leader in sugarcane production. Between 2011 and 2012, the national sugarcane production surpassed 530 million tons of raw agricultural materials (MAPA Ministry of Agriculture and Supply 2011). Sugarcane molasses are consumed in the production of ethanol (for use in vehicles) and sugar. However, the remainder of the sugarcane tissue (graminea) is composed of bagasse.

Until recently, the bagasse was discarded in an indiscriminate manner that resulted in significant environmental impacts. Technologies have been developed to change this situation by reusing the bagasse to produce steam and electricity for the sugar and alcohol production processes, making these plants self-sufficient with respect to energy. Thus, sugarcane is potentially important. In addition, cogeneration has become one of the most efficient technologies for the rational use of primary fuel to produce electricity and heat (Bocci et al. 2009; Tina and Passarello 2011).

The prospect of exporting electricity to the national grid also during the idle periods of distilleries and annex plants motivates the Brazilian sugar/alcohol sector to invest in these systems. This study aims to provide basis and decisionmaking components to this initiative by evaluating actions (within technical and environmental standards) for improving the performance of electrical energy cogeneration units by burning sugarcane bagasse.

\section{Analysis methods}

The evaluation of technical performance consisted of the following stages: (1) proposing improvement actions for a cogeneration system based on the Rankine cycle - traditionally employed by Brazilian sugarcane mills. These actions, as well as the thermodynamic operating conditions of the cogeneration system, will be organized as scenarios in order to facilitate the analysis of performance to be made later. (2) It also includes analyzing the potential energy efficiency results, (3) analyzing the environmental performance of the product system from an LCA perspective, and finally (4) being able to get indications that point to the best arrangement for the production of electricity through cogeneration from sugarcane bagasse, both within the fields of energy efficiency and environmental performance. More information about the product system is described in Fig. 1 and discussed further ahead in the "Goal and scope definition" section.

\subsection{Improvement action propositions: the case scenarios}

In order to achieve the objective mentioned above, two operating conditions for the cogeneration system were analyzed, including the properties of the steam as it leaves the boiler-at 67 bar and $4800^{\circ} \mathrm{C}$ or 100 bar and $520^{\circ} \mathrm{C}$, respectively. These operating pressures are realistic and were established from the current trend of the Brazilian sugarcane sector (Dias et al. 2011). For each condition, different energy recovery alternatives were formulated. They were expressed as conventional, reheating, regenerative, and composite (reheating+regeneration) cycles. The arrangement established between the thermodynamic operating conditions, and the alternatives for energy recovery, provided the formulation of eight study scenarios. These scenarios are detailed in Table 1.

The theoretical basis for proposing such arrangements for cogeneration systems came from the experience of efficiency improvement in thermoelectric plants by using the same technology described by Moran \& Shapiro (2008).

In the conventional cycle depicted in Fig. 2, superheated steam from the steam generator expands through the turbine until the condenser pressure is reached. The cycle is complete when the turbine exhaust steam condenses and returns to the boiler with the process condensate. In the reheating cycle depicted in Fig. 3, the steam does not expand to reach the condenser pressure in a single stage. Instead, the steam 
Fig. 1 Description of the product system under study

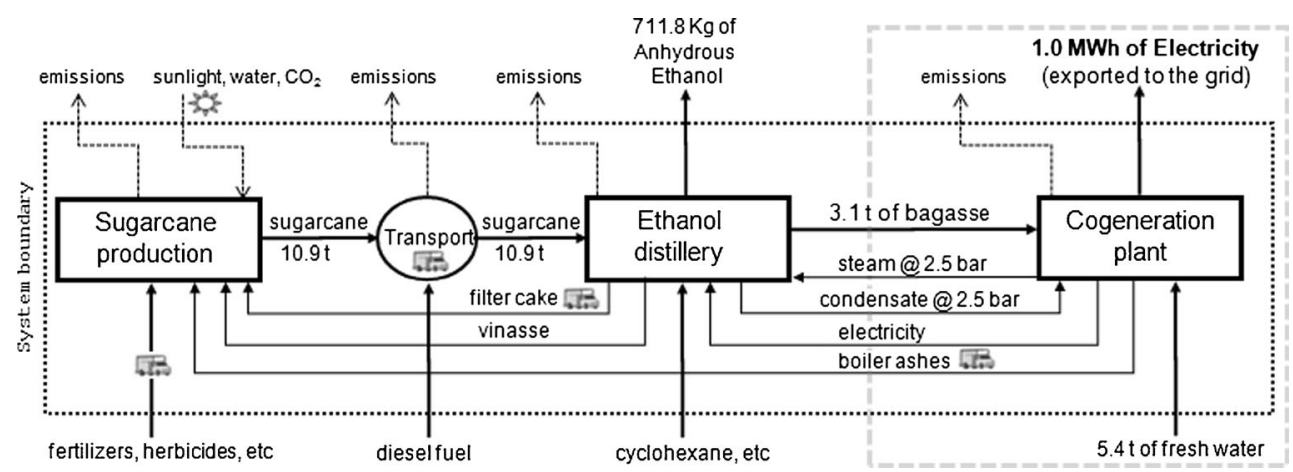

expands through a first-stage turbine and is reheated in the steam generator. The flow after reheating is reinjected into the turbine in the second stage. The regenerative cycle assumes intermediate withdrawals of steam along the turbine. These steam flows are used to heat the boiler feedwater, which occurs through indirect contact in heat exchangers as showed in Fig. 4. Finally, the composite cycle consists of reheating and regeneration in a single cycle as depicted in Fig. 5.

The potential gains achieved by the improvement actions were analyzed by comparing the overall energy efficiency results and the amount of electricity delivery to the power grid in each scenario with those of the standard scenario (SS).

\subsection{Thermodynamic analysis}

The models developed to represent the conventional cycle along with the steam reheating, regeneration, and composite cycles are represented in Figs. 2, 3, 4, and 5. For all case scenarios, dry saturated steam was extracted from the turbine at a pressure of 2.5 bar for using in the ethanol production process and for reaching the set deaeration point $\left(110^{\circ} \mathrm{C}\right)$ before returning to the boiler. The turbine exhaust steam flows into a condenser unit at a pressure of 0.1 bar. The liquid fraction passes through a deaerator prior to reintroduction into the boiler at the end of the cycle.

Table 1 Electricity production scenarios for the cogeneration systems based on different steam properties and energy recovery conditions

\begin{tabular}{ll}
$\begin{array}{l}\text { Case } \\
\text { scenario }\end{array}$ & Description \\
\hline $\begin{array}{l}\text { Standard } \\
\text { (SS) }\end{array}$ & Conventional vapor power cycle at 67 bar and $480{ }^{\circ} \mathrm{C}$ \\
I & Reheating vapor power cycle at 67 bar and $480{ }^{\circ} \mathrm{C}$ \\
II & Regenerative vapor power cycle at 67 bar and $480{ }^{\circ} \mathrm{C}$ \\
III & Reheat-regenerative vapor power cycle at 67 bar and $480{ }^{\circ} \mathrm{C}$ \\
IV & Conventional vapor power cycle at 100 bar and $520{ }^{\circ} \mathrm{C}$ \\
V & Reheating vapor power cycle at 100 bar and $520{ }^{\circ} \mathrm{C}$ \\
VI & Regenerative vapor power cycle at 100 bar and $520{ }^{\circ} \mathrm{C}$ \\
VII & Reheat-regenerative vapor power cycle at 100 bar and $520{ }^{\circ} \mathrm{C}$ \\
\hline
\end{tabular}

In the reheating cycle (Fig. 3), superheated steam is extracted from the turbine at an optimum pressure of 20 to 25 bar for both work conditions in this study. This variation was determined from parametric analysis by applying the graphic inspection method. The turbine exhaust steam followed the same trajectories as that in the conventional cycle. In the regenerative cycle (Fig. 4), the number of heat exchangers was also determined by parametric analysis, and it was realized that the use of more than three units in series to heat the feedwater has slightly increased the efficiency of the regenerative cycle. In light of this finding, it was decided to keep an arrangement with three heat exchangers units.

The main thermodynamic indicators analyzed were the energy efficiency, the net power output, and net power exported to the grid. The energy efficiency of a cogeneration system was defined as the ratio between the useful energy - i.e., the thermal energy used for ethanol production plus the total electricity obtained by the cogeneration - and the total amount of energy entered in the boiler. The net power output consists of the difference between the total energy produced in the cogeneration unit and the power consumed within the Rankine cycle by the pumps. The net power exported is the power delivered to grid, and can be determined by the difference between the net power output, and the power required for ethanol production.

The case scenarios were modeled using the Engineering Equation Solver (EES) software. This computational resource is useful to provide thermodynamically robust solutions for energy systems. For this purpose, the EES solves a set of algebraic equations, and it is particularly useful for design problems in which the effects of one or more parameters need to be determined. In this paper, EES was applied to make an analysis varying just one parameter at a time in a suitable range in order to find the optimum result. The equations used in the models were based on the principles of conservation of mass and energy applied for each step of the Rankine cycles.

\subsection{Environmental assessment}

To evaluate the environmental performance, an LCA was used to focus on the cogeneration plant "from cradle-to-gate". The goal and scope of this evaluation was to study the production and delivery of electricity to the grid. Under these conditions, 


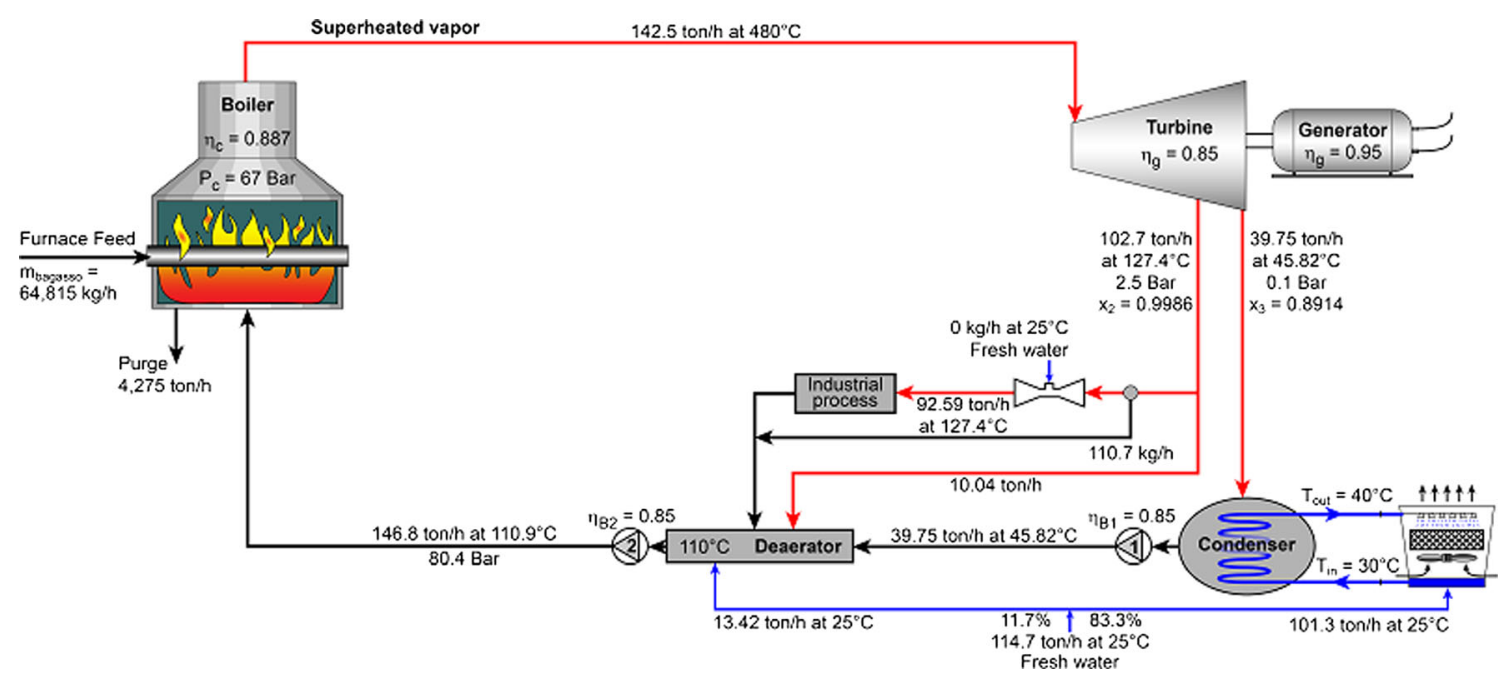

Fig. 2 Conventional steam power cycle for a cogeneration plant

the product system considered sugarcane in the agricultural production stage, its transport to the distillery, its use for anhydrous ethanol production, and its use for the cogeneration of electrical energy. For the product system model, it was based on the agricultural practice regularly developed in the state of São Paulo where the primary data were collected. The average agricultural productivity of Sao Paulo reaches 90 t/ha, and it is responsible for $61 \%$ of total Brazilian sugarcane production (CGEE 2008). In addition, the reuse of industrial residues, such as filter cakes, vinasse, and boiler ashes, and burning of the growing area in preparation for harvest were considered (Sousa and Macedo 2010). Details and conditions associated with this methodological step will be provided below.

\section{Goal and scope definition}

The calculation employed in the simulations for all scenarios was based on anhydrous ethanol production in an autonomous sugarcane distillery with a crushing capacity of $2.0 \mathrm{Mt}$ of sugarcane per season (180 days).

It corresponds to a sugarcane bagasse input of $64,815 \mathrm{~kg} / \mathrm{h}$ in the boiler furnace. It was considered that $100 \%$ of the bagasse is sent to the boiler and converted into thermal energy. It means that bagasse does not cross the system boundary to be sold or disposed.

The thermal energy consumption (400 kg of saturated vapor at $2.5 \mathrm{bar})$ and electricity $(30 \mathrm{kWh} / \mathrm{t}$ of processed sugarcane) required for ethanol production are not affected in the previously described scenarios. The excess electrical energy generated by the cogeneration unit is exported to the electricity grid.

The LCA study was conducted based on the theoretical registration described in ISO 14040 (2006a) and ISO 14044 (2006b). Thus, based on the objective definition, the initiative proposes to conduct an environmental analysis of actions that improve the performance of cogeneration units by burning sugarcane bagasse.

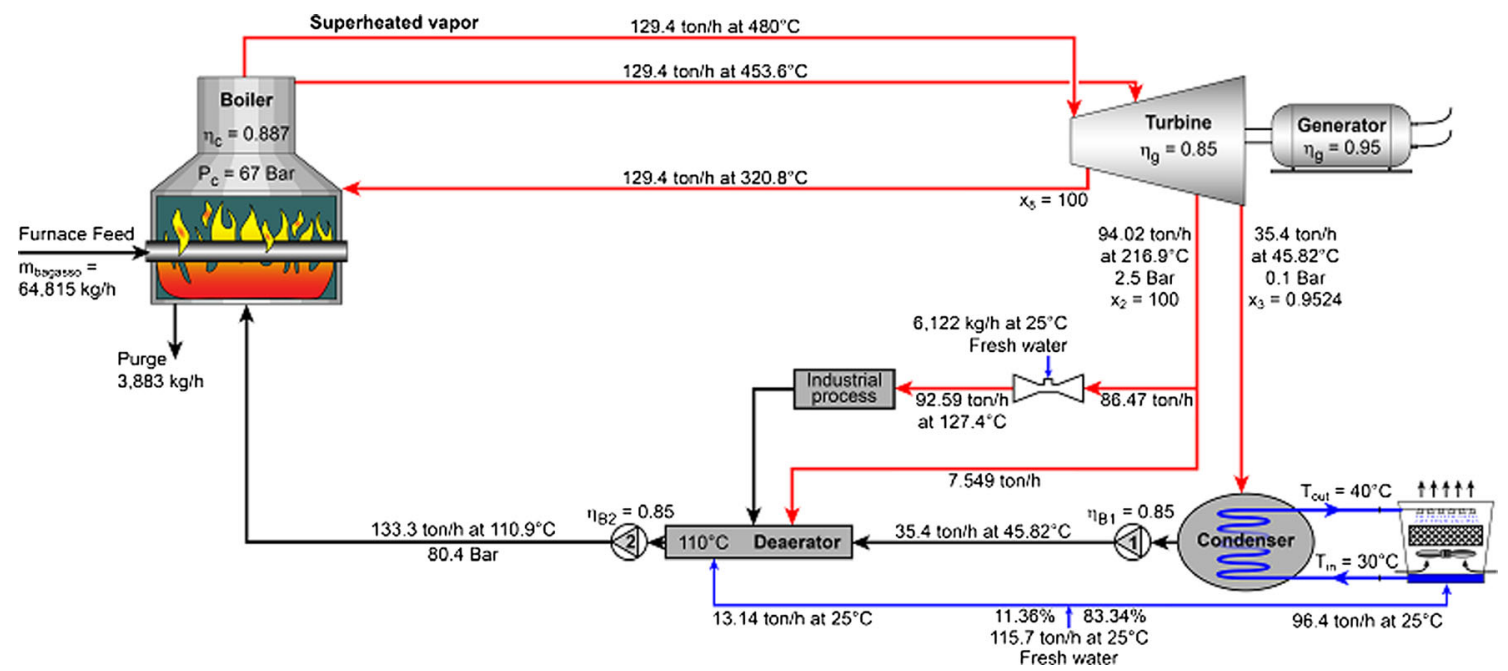

Fig. 3 Reheating steam power cycle for a cogeneration plant 


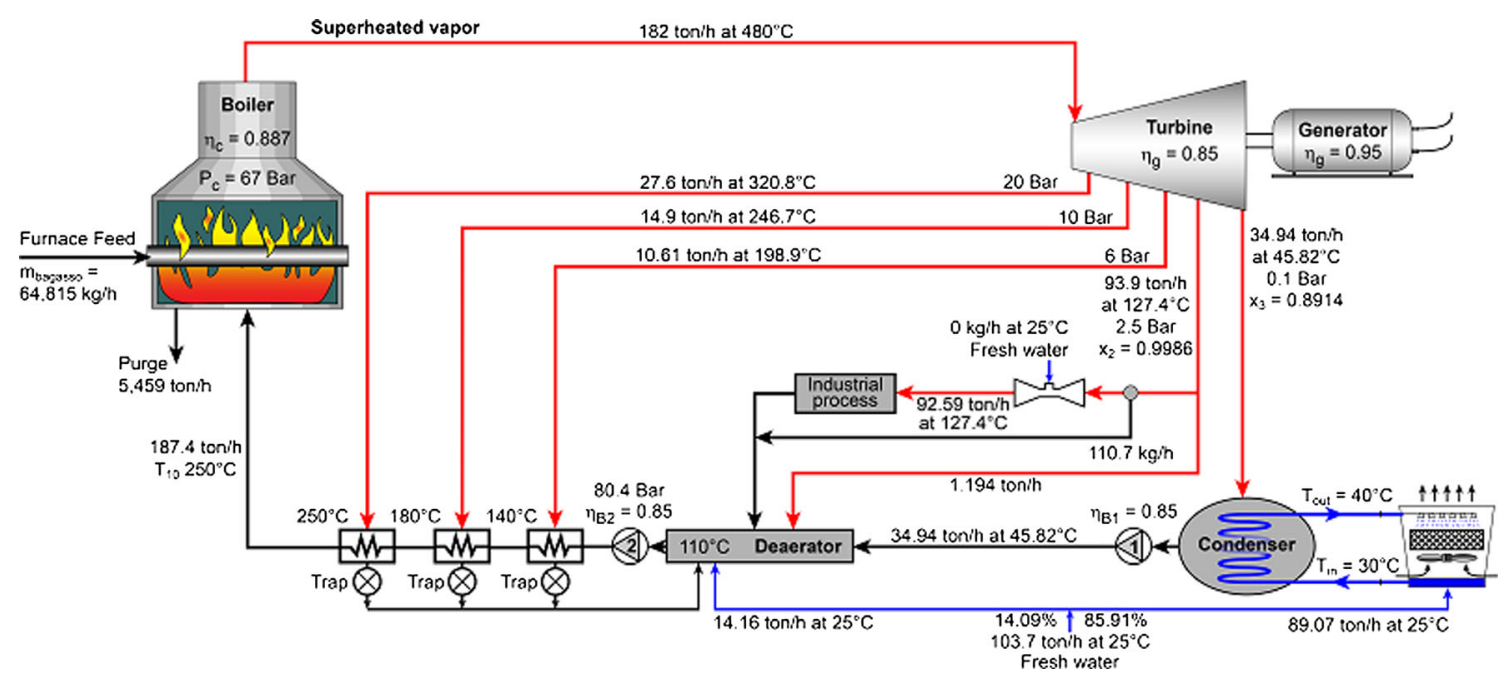

Fig. 4 Regenerative steam power cycle of a cogeneration plant

Regarding the scope definition, the following conditions were established.

Functional unit - to the delivery of $1.0 \mathrm{MWh}$ of electricity to the power grid using a cogeneration system under the conditions mentioned above.

Product system - includes the sugarcane agricultural production stages, transport, the industrial production of ethanol, and the electricity cogeneration. The diagram of the product system appears in Fig. 1. The ethanol production rate was kept constant for all the scenarios, once the processing alternatives under study have been simulated only at the cogeneration plant, always admitting the same sugarcane crushing rate.

Data source - secondary data served to model the product systems, with the exception of the SS, for which primary data were collected and were referred to as the equipment's performance data.
Data quality - the Temporal Coverage consisted of the 2year period of 2009 and 2010. The geographical coverage comprised the state of Sao Paulo. Technical coverage considered the processes and technical features previously described.

Allocation - the environmental load from the agricultural step and industrial process of ethanol production are allocated between ethanol and sugarcane bagasse. Thereby, it was taken into account an allocation criterion based on energy content, which was expressed in terms of the lower heating value (LHV) of the components.

Types of impact and methodology of LCIA - to obtain an environmental performance profile with a wide spectrum as generated by grouping analytical indicators, the method $\mathrm{ReCiPe}$ Midpoint $(\mathrm{H})$ version 1.08 was selected (Goedkoop et al. 2013).

All of the impact categories from ReCiPe were considered, except for ionization radiation, marine eutrophication and

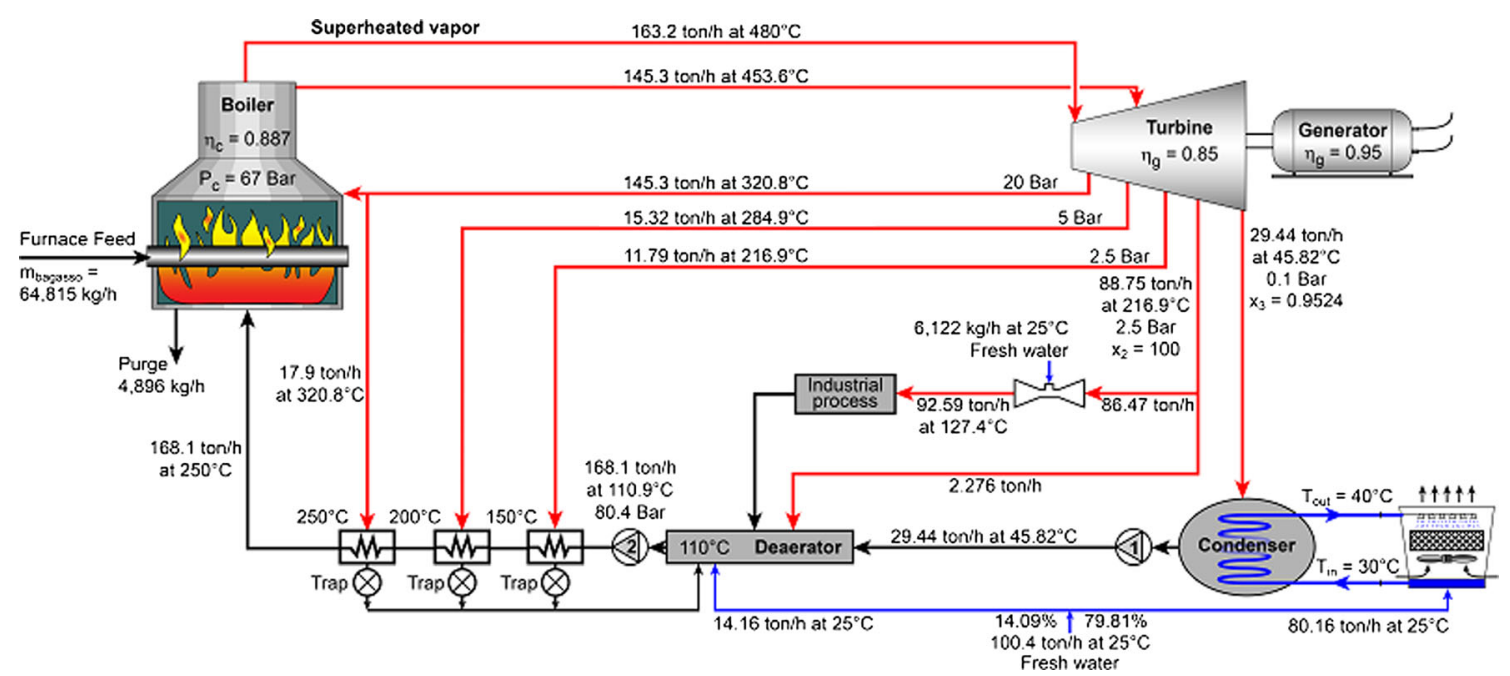

Fig. 5 The reheat-regenerative steam power cycle for a cogeneration plant 
Fig. 6 Thermodynamic results of the case scenarios at 67 bar in relation to the SS

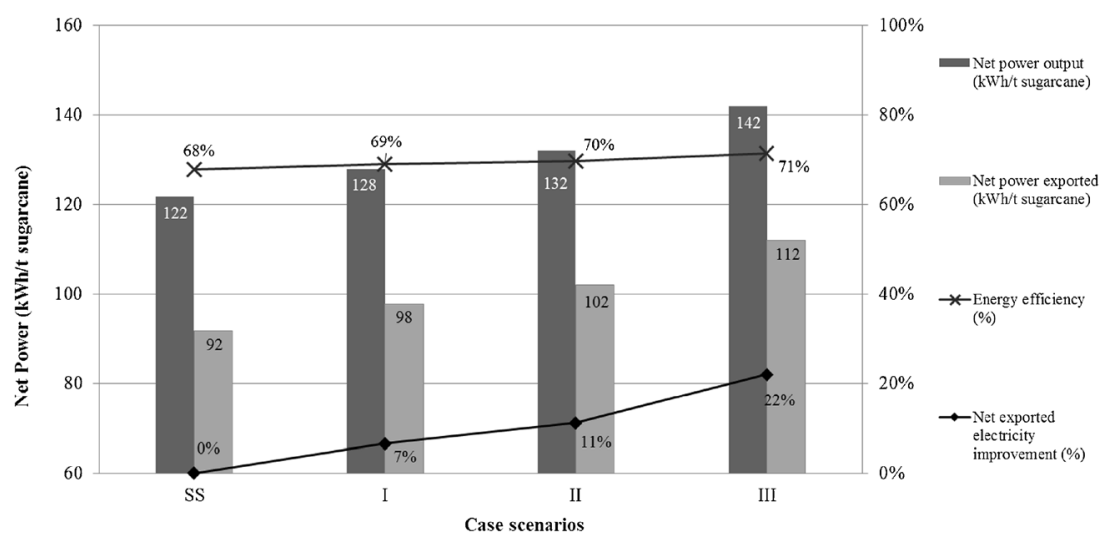

marine ecotoxicity, ozone and metal depletion and urban land occupation. The features of the object of study and the character analysis supported this decision.

Contributions in terms of ionization radiation were not taken into account due to the low expressivity of modal nuclear emission in the national energy matrix. Developments in the form of eutrophication and ecotoxicity on marine biota are outside the scope of application of the study, as well as urban land occupation.

Depletions of ozone and metals were dismissed after the product system model has analyzed its significance in terms of the potential contributors to both environmental impacts. In addition, infrastructure issues, as well as capital goods, were disregarded after the simulations carried out have showed discrete influence on the environmental impacts.

As a premise of the study, it was established that the resource consumption and emissions, as well as the operating conditions of the unit processes of "sugarcane production" and "sugarcane crushing"- which is part of the subsystem "ethanol distillery" - are the same for all scenarios under evaluation. Therefore, the environmental load amounted by the bagasse into the cogeneration plant was either the same for any of the simulations. This assumption was held in order to evaluate the effects in terms of energy efficiency and under the environment of producing increasing electricity in a cogeneration unit using the same amount of natural resources.

\section{Results}

\subsection{Thermodynamic analysis}

Figures 6 and 7 provide the overall energy efficiency results and the relative gains in terms of the net power exported to the grid for each case scenario (measured relative to the SS). Based on the results, it is possible to see that the energy efficiency improves as the pressure at which the vapor leaves the boiler increases. In addition, the energy efficiency improves during the reheat-regenerative steam power cycle relative to the other cycles. For scenario VII, which had the greatest overall energy efficiency, the net power output reached $152 \mathrm{kWh} / \mathrm{t}$ of sugarcane and the net power exported reached $122 \mathrm{kWh} / \mathrm{t}$ of sugarcane. This result corresponds to an increase of $33 \%$ relative to the performance of the SS.

Figures 8 and 9 show that the makeup water consumption in the cooling tower was reduced by $32 \%$ from SS to scenario VII. On the other hand, the makeup water supplied to the boiler was increased by $58 \%$ relative to the initial SS. Comparing the best case scenario to the SS, it is possible to notice an overall reduction of $21 \%$ in the water consumption for the Rankine cycle. The introduction of a reheating and regeneration independently to the conventional Rankine cycle at 67 bar caused a reduction of 5 and $12.1 \%$ in terms of cooling water makeup, respectively. Figure 8 also shows that
Fig. 7 Thermodynamic results of the case scenarios at 100 bar in relation to the SS

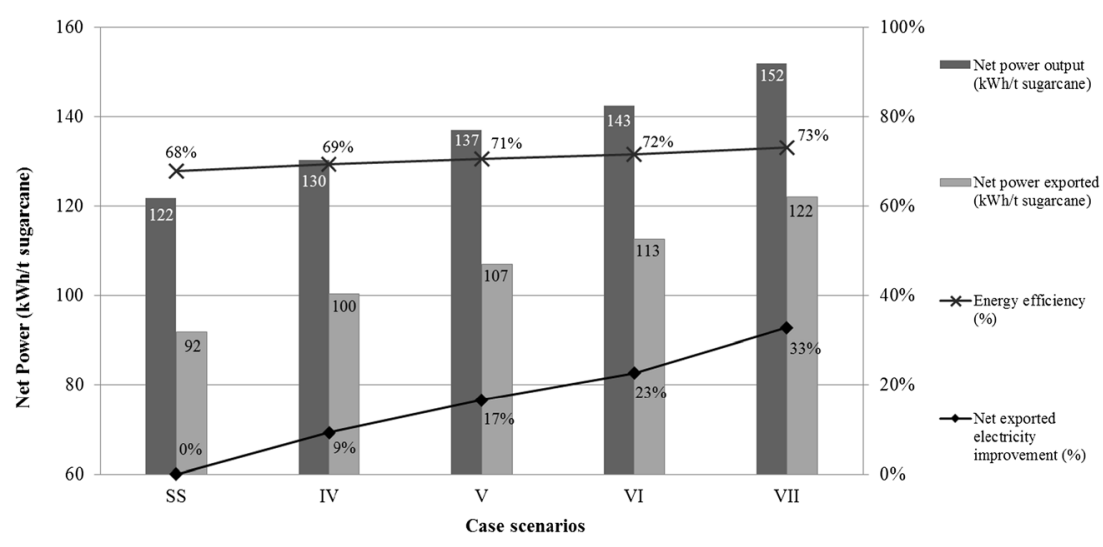


Fig. 8 Freshwater consumption results of the case scenarios at 67 bar in relation to the SS

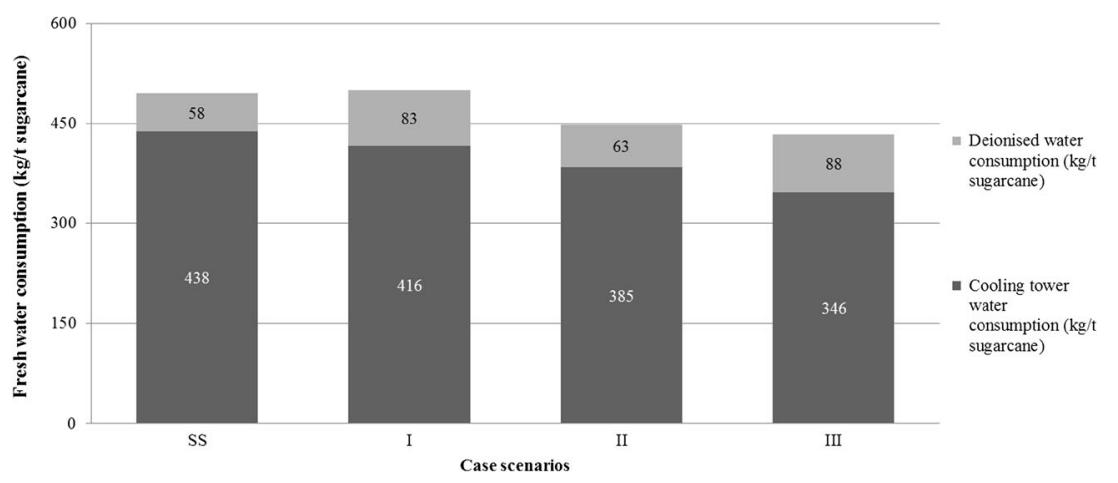

the combination of reheating and regeneration applied to the Rankine cycle (case scenario III) caused a reduction of $21 \%$ of the cooling water makeup.

The case scenarios at 100 bar showed the same trend. The more energy is lost in the condenser, the more cooling water flow through the condenser is required. The cooling water comes from the evaporative cooling tower. That is the reason of the better the energy efficiency of the case scenario, the less energy wasted in the cooling tower. As a result, the overall freshwater consumption decreases.

\subsection{Environmental assessment}

The environmental performance of the product system under analysis is indicated in Tables 2 and 3. Table 2 describes, as a Life Cycle Inventory (LCI), the main consumption of resources - both natural, as obtained from the TechnoSphereand emissions - to air, water, and soil - for the eight operation scenarios of the Rankine cycle under study. Table 3 displays the environmental performance profile results generated by the LCIA for the eight case scenarios using the method ReCiPe Midpoint $(\mathrm{H})$-version 1.08. Only a broad analysis performed both in the levels of LCI and LCIA enables a clear, comprehensive, and accurate picture of the consequences caused by the electricity production via cogeneration and its delivery to the grid.

From a generalist point of view, this approach revealed unanimously for all the scenarios under study that the agricultural stage - related to the unit process "sugarcane production"- provides more negative effects to the environment than any other elements of the product system. It is followed in descending order of importance for "soil amendment", "transportation", "ethanol distillery", and the "cogeneration plant". In the cogeneration plant, the less significant contributions from all of the product system were recorded. This is justified because the unit presents a productive arrangement that comprises closed loops of thermal and electrical energy and a partial recycle of water.

It is possible to observe from the obtained results that the improving energy performance of the system from the adoption of alternative technologies and the increased vapor pressure output is accompanied by reduced environmental impacts for all evaluated categories. Besides, an analysis performed just under the environmental approach points out that the improvements remain strictly equal in relation to the SS for all the impact categories considered by the study, if they are expressed as percentage contributions. This conclusion can be observed in Fig. 10.

It is important to emphasize that the results presented in Table 3 are strongly dependent of the allocation criteria. As mentioned in the "Goal and scope definition" section, the only allocation of environmental loads performed in this study occurred between the ethanol and bagasse. It was carried out in terms of energy content, expressed as LHV. According to this approach, the bagasse shifts about $50 \%$ of the total environmental load associated to the agricultural process and the industrial stage of sugarcane crushing to the cogeneration plant.
Fig. 9 Fresh water consumption results of the case scenarios at 100 bar in relation to the SS

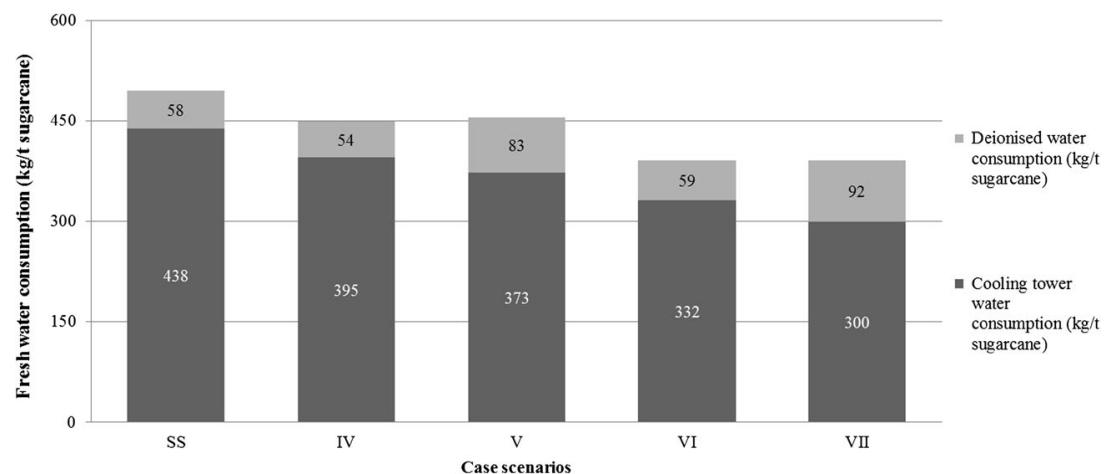


Table 2 Main environmental impacts associated to the delivery of 1.0 MWh of electricity to the power grid, obtained from cogeneration

\begin{tabular}{|c|c|c|c|c|c|c|c|c|c|}
\hline Environmental loads & Unit & SS & I & II & III & IV & $\mathrm{V}$ & VI & VII \\
\hline \multicolumn{10}{|l|}{ INPUTS } \\
\hline \multicolumn{10}{|l|}{ Inputs from nature } \\
\hline Gas, natural, and in ground & $\mathrm{m}^{3}$ & $1.12 \mathrm{E}+01$ & $1.01 \mathrm{E}+01$ & $1.05 \mathrm{E}+01$ & $9.17 \mathrm{E}+00$ & $1.02 \mathrm{E}+01$ & $9.11 \mathrm{E}+00$ & $9.60 \mathrm{E}+00$ & $8.42 \mathrm{E}+00$ \\
\hline $\begin{array}{l}\text { Occupation, arable, and } \\
\text { non-irrigated }\end{array}$ & $\mathrm{m}^{2} \mathrm{a}$ & $7.99 \mathrm{E}+02$ & $7.19 \mathrm{E}+02$ & $7.50 \mathrm{E}+02$ & $6.55 \mathrm{E}+02$ & $7.32 \mathrm{E}+02$ & $6.52 \mathrm{E}+02$ & $6.86 \mathrm{E}+02$ & $6.02 \mathrm{E}+02$ \\
\hline Oil, crude, and in ground & $\mathrm{t}$ & $3.04 \mathrm{E}-02$ & $2.73 \mathrm{E}-02$ & $2.85 \mathrm{E}-02$ & $2.49 \mathrm{E}-02$ & $2.78 \mathrm{E}-02$ & $2.48 \mathrm{E}-02$ & $2.61 \mathrm{E}-02$ & $2.29 \mathrm{E}-02$ \\
\hline $\begin{array}{l}\text { Transformation, from arable, } \\
\text { nonirrigated }\end{array}$ & $\mathrm{m}^{2}$ & $4.23 \mathrm{E}+00$ & $3.81 \mathrm{E}+00$ & $3.97 \mathrm{E}+00$ & $3.47 \mathrm{E}+00$ & $3.87 \mathrm{E}+00$ & $3.45 \mathrm{E}+00$ & $3.63 \mathrm{E}+00$ & $3.18 \mathrm{E}+00$ \\
\hline $\begin{array}{l}\text { Transformation, from pasture and } \\
\text { meadow, extensive }\end{array}$ & $\mathrm{m}^{2}$ & $1.75 \mathrm{E}+01$ & $1.57 \mathrm{E}+01$ & $1.64 \mathrm{E}+01$ & $1.43 \mathrm{E}+01$ & $1.60 \mathrm{E}+01$ & $1.43 \mathrm{E}+01$ & $1.50 \mathrm{E}+01$ & $1.32 \mathrm{E}+01$ \\
\hline $\begin{array}{l}\text { Transformation, from shrub land, } \\
\text { sclerophyllous }\end{array}$ & $\mathrm{m}^{2}$ & $2.21 \mathrm{E}-01$ & $1.99 \mathrm{E}-01$ & $2.08 \mathrm{E}-01$ & $1.82 \mathrm{E}-01$ & $2.03 \mathrm{E}-01$ & $1.81 \mathrm{E}-01$ & $1.90 \mathrm{E}-01$ & $1.67 \mathrm{E}-01$ \\
\hline $\begin{array}{l}\text { Transformation, to arable, } \\
\text { nonirrigated }\end{array}$ & $\mathrm{m}^{2}$ & $2.20 \mathrm{E}+01$ & $1.98 \mathrm{E}+01$ & $2.06 \mathrm{E}+01$ & $1.80 \mathrm{E}+01$ & $2.01 \mathrm{E}+01$ & $1.79 \mathrm{E}+01$ & $1.88 \mathrm{E}+01$ & $1.65 \mathrm{E}+01$ \\
\hline Water, at the surface & $\mathrm{m}^{3}$ & $1.29 \mathrm{E}+01$ & $1.14 \mathrm{E}+01$ & $1.22 \mathrm{E}+01$ & $1.03 \mathrm{E}+01$ & $1.17 \mathrm{E}+01$ & $9.99 \mathrm{E}+00$ & $1.09 \mathrm{E}+01$ & $9.25 \mathrm{E}+00$ \\
\hline \multicolumn{10}{|l|}{ Inputs from TechnoSphere } \\
\hline Agricultural machinery, general & $\mathrm{kg}$ & $7.28 \mathrm{E}-01$ & $6.55 \mathrm{E}-01$ & $6.84 \mathrm{E}-01$ & $5.97 \mathrm{E}-01$ & $6.65 \mathrm{E}-01$ & $5.93 \mathrm{E}-01$ & $6.24 \mathrm{E}-01$ & $5.48 \mathrm{E}-01$ \\
\hline $\begin{array}{l}\text { Ammonium nitrate } \\
\text { phosphate, as } \mathrm{N}\end{array}$ & $\mathrm{kg}$ & $7.56 \mathrm{E}-01$ & $6.80 \mathrm{E}-01$ & $7.10 \mathrm{E}-01$ & $6.20 \mathrm{E}-01$ & $6.91 \mathrm{E}-01$ & $6.15 \mathrm{E}-01$ & $6.48 \mathrm{E}-01$ & $5.69 \mathrm{E}-01$ \\
\hline Diesel & $\mathrm{kg}$ & $1.75 \mathrm{E}+01$ & $1.58 \mathrm{E}+01$ & $1.64 \mathrm{E}+01$ & $1.44 \mathrm{E}+01$ & $1.60 \mathrm{E}+01$ & $1.42 \mathrm{E}+01$ & $1.50 \mathrm{E}+01$ & $1.32 \mathrm{E}+01$ \\
\hline Carbofuran & $\mathrm{kg}$ & $3.83 \mathrm{E}-02$ & $3.45 \mathrm{E}-02$ & $3.60 \mathrm{E}-02$ & $3.14 \mathrm{E}-02$ & $3.50 \mathrm{E}-02$ & $3.12 \mathrm{E}-02$ & $3.28 \mathrm{E}-02$ & $2.88 \mathrm{E}-02$ \\
\hline Diuron & $\mathrm{kg}$ & $8.90 \mathrm{E}-03$ & $8.01 \mathrm{E}-03$ & $8.36 \mathrm{E}-03$ & $7.30 \mathrm{E}-03$ & $8.13 \mathrm{E}-03$ & $7.24 \mathrm{E}-03$ & $7.63 \mathrm{E}-03$ & $6.70 \mathrm{E}-03$ \\
\hline Fipronil & $\mathrm{kg}$ & $3.65 \mathrm{E}-03$ & $3.29 \mathrm{E}-03$ & $3.43 \mathrm{E}-03$ & $2.99 \mathrm{E}-03$ & $3.34 \mathrm{E}-03$ & $2.97 \mathrm{E}-03$ & $3.13 \mathrm{E}-03$ & $2.75 \mathrm{E}-03$ \\
\hline Glyphosate & $\mathrm{kg}$ & $2.08 \mathrm{E}-02$ & $1.87 \mathrm{E}-02$ & $1.95 \mathrm{E}-02$ & $1.71 \mathrm{E}-02$ & $1.90 \mathrm{E}-02$ & $1.69 \mathrm{E}-02$ & $1.78 \mathrm{E}-02$ & $1.57 \mathrm{E}-02$ \\
\hline Growth regulators & $\mathrm{kg}$ & $7.71 \mathrm{E}-03$ & $6.94 \mathrm{E}-03$ & $7.24 \mathrm{E}-03$ & $6.32 \mathrm{E}-03$ & $7.05 \mathrm{E}-03$ & $6.28 \mathrm{E}-03$ & $6.61 \mathrm{E}-03$ & $5.81 \mathrm{E}-03$ \\
\hline Harvester & $\mathrm{kg}$ & $2.46 \mathrm{E}-01$ & $2.21 \mathrm{E}-01$ & $2.31 \mathrm{E}-01$ & $2.02 \mathrm{E}-01$ & $2.25 \mathrm{E}-01$ & $2.00 \mathrm{E}-01$ & $2.11 \mathrm{E}-01$ & $1.85 \mathrm{E}-01$ \\
\hline Lime, hydrated and packed & $\mathrm{kg}$ & $4.55 \mathrm{E}+00$ & $4.10 \mathrm{E}+00$ & $4.27 \mathrm{E}+00$ & $3.73 \mathrm{E}+00$ & $4.16 \mathrm{E}+00$ & $3.70 \mathrm{E}+00$ & $3.90 \mathrm{E}+00$ & $3.43 \mathrm{E}+00$ \\
\hline Potassium chloride, as $\mathrm{K}_{2} \mathrm{O}$ & $\mathrm{kg}$ & $6.09 \mathrm{E}+00$ & $5.48 \mathrm{E}+00$ & $5.72 \mathrm{E}+00$ & $4.99 \mathrm{E}+00$ & $5.57 \mathrm{E}+00$ & $4.96 \mathrm{E}+00$ & $5.22 \mathrm{E}+00$ & $4.59 \mathrm{E}+00$ \\
\hline Single superphosphate, as $\mathrm{P}_{2} \mathrm{O}_{5}$ & $\mathrm{~kg}$ & $2.74 \mathrm{E}+00$ & $2.47 \mathrm{E}+00$ & $2.57 \mathrm{E}+00$ & $2.25 \mathrm{E}+00$ & $2.50 \mathrm{E}+00$ & $2.23 \mathrm{E}+00$ & $2.35 \mathrm{E}+00$ & $2.06 \mathrm{E}+00$ \\
\hline Urea, as $\mathrm{N}$ & $\mathrm{kg}$ & $5.02 \mathrm{E}+00$ & $4.52 \mathrm{E}+00$ & $4.71 \mathrm{E}+00$ & $4.12 \mathrm{E}+00$ & $4.59 \mathrm{E}+00$ & $4.09 \mathrm{E}+00$ & $4.30 \mathrm{E}+00$ & $3.78 \mathrm{E}+00$ \\
\hline Tractor & $\mathrm{kg}$ & $5.12 \mathrm{E}-01$ & $4.61 \mathrm{E}-01$ & $4.81 \mathrm{E}-01$ & $4.20 \mathrm{E}-01$ & $4.68 \mathrm{E}-01$ & $4.17 \mathrm{E}-01$ & $4.39 \mathrm{E}-01$ & $3.86 \mathrm{E}-01$ \\
\hline Vinasse, from sugarcane & $\mathrm{m}^{3}$ & $7.15 \mathrm{E}+00$ & $6.44 \mathrm{E}+00$ & $6.71 \mathrm{E}+00$ & $5.86 \mathrm{E}+00$ & $6.54 \mathrm{E}+00$ & $5.82 \mathrm{E}+00$ & $6.13 \mathrm{E}+00$ & $5.38 \mathrm{E}+00$ \\
\hline \multicolumn{10}{|l|}{ OUTPUTS } \\
\hline \multicolumn{10}{|l|}{ Emissions to air } \\
\hline $\mathrm{NH}_{3}$ & $\mathrm{~kg}$ & $2.19 \mathrm{E}+00$ & $1.97 \mathrm{E}+00$ & $2.05 \mathrm{E}+00$ & $1.79 \mathrm{E}+00$ & $2.00 \mathrm{E}+00$ & $1.78 \mathrm{E}+00$ & $1.88 \mathrm{E}+00$ & $1.65 \mathrm{E}+00$ \\
\hline $\mathrm{Cd}$ & $\mathrm{kg}$ & $1.61 \mathrm{E}-04$ & $1.45 \mathrm{E}-04$ & $1.51 \mathrm{E}-04$ & $1.32 \mathrm{E}-04$ & $1.48 \mathrm{E}-04$ & $1.31 \mathrm{E}-04$ & $1.38 \mathrm{E}-04$ & $1.21 \mathrm{E}-04$ \\
\hline Carbon dioxide, biogenic & $\mathrm{kg}$ & $1,32 \mathrm{E}+03$ & $1.18 \mathrm{E}+03$ & $1.23 \mathrm{E}+03$ & $1.08 \mathrm{E}+03$ & $1.20 \mathrm{E}+03$ & $1.07 \mathrm{E}+03$ & $1.13 \mathrm{E}+03$ & $9.90 \mathrm{E}+02$ \\
\hline $\mathrm{CO}_{2}$, fossil & $\mathrm{kg}$ & $1.50 \mathrm{E}+02$ & $1.35 \mathrm{E}+02$ & $1.41 \mathrm{E}+02$ & $1.23 \mathrm{E}+02$ & $1.37 \mathrm{E}+02$ & $1.22 \mathrm{E}+02$ & $1.29 \mathrm{E}+02$ & $1.13 \mathrm{E}+02$ \\
\hline $\mathrm{CO}_{2}$, land transformation & $\mathrm{kg}$ & $2.94 \mathrm{E}+02$ & $2.65 \mathrm{E}+02$ & $2.76 \mathrm{E}+02$ & $2.41 \mathrm{E}+02$ & $2.69 \mathrm{E}+02$ & $2.40 \mathrm{E}+02$ & $2.52 \mathrm{E}+02$ & $2.21 \mathrm{E}+02$ \\
\hline $\mathrm{CO}$, biogenic & $\mathrm{kg}$ & $2.20 \mathrm{E}+01$ & $1.98 \mathrm{E}+01$ & $2.06 \mathrm{E}+01$ & $1.80 \mathrm{E}+01$ & $2.01 \mathrm{E}+01$ & $1.79 \mathrm{E}+01$ & $1.89 \mathrm{E}+01$ & $1.66 \mathrm{E}+01$ \\
\hline $\mathrm{CO}$, fossil & $\mathrm{kg}$ & $8.30 \mathrm{E}+01$ & $7.47 \mathrm{E}+01$ & $7.79 \mathrm{E}+01$ & $6.81 \mathrm{E}+01$ & $7.60 \mathrm{E}+01$ & $6.77 \mathrm{E}+01$ & $7.12 \mathrm{E}+01$ & $6.25 \mathrm{E}+01$ \\
\hline $\mathrm{Cu}$ & $\mathrm{kg}$ & $2.62 \mathrm{E}-02$ & $2.36 \mathrm{E}-02$ & $2.46 \mathrm{E}-02$ & $2.15 \mathrm{E}-02$ & $2.40 \mathrm{E}-02$ & $2.13 \mathrm{E}-02$ & $2.25 \mathrm{E}-02$ & $1.97 \mathrm{E}-02$ \\
\hline $\mathrm{CH}_{4}$ & $\mathrm{~kg}$ & $3.54 \mathrm{E}-01$ & $3.19 \mathrm{E}-01$ & $3.32 \mathrm{E}-01$ & $2.90 \mathrm{E}-01$ & $3.24 \mathrm{E}-01$ & $2.89 \mathrm{E}-01$ & $3.04 \mathrm{E}-01$ & $2.67 \mathrm{E}-01$ \\
\hline $\mathrm{CH}_{4}$, biogenic & $\mathrm{kg}$ & $6.59 \mathrm{E}-01$ & $5.93 \mathrm{E}-01$ & $6.19 \mathrm{E}-01$ & $5.40 \mathrm{E}-01$ & $6.03 \mathrm{E}-01$ & $5.37 \mathrm{E}-01$ & $5.66 \mathrm{E}-01$ & $4.96 \mathrm{E}-01$ \\
\hline $\mathrm{CH}_{4}$, fossil & $\mathrm{kg}$ & $2.13 \mathrm{E}+00$ & $1.92 \mathrm{E}+00$ & $2.00 \mathrm{E}+00$ & $1.75 \mathrm{E}+00$ & $1.95 \mathrm{E}+00$ & $1.74 \mathrm{E}+00$ & $1.83 \mathrm{E}+00$ & $1.61 \mathrm{E}+00$ \\
\hline $\mathrm{N}_{2} \mathrm{O}$ & $\mathrm{kg}$ & $2.18 \mathrm{E}+00$ & $1.96 \mathrm{E}+00$ & $2.05 \mathrm{E}+00$ & $1.79 \mathrm{E}+00$ & $2.00 \mathrm{E}+00$ & $1.78 \mathrm{E}+00$ & $1.87 \mathrm{E}+00$ & $1.64 \mathrm{E}+00$ \\
\hline NMVOC, unspecified origin & $\mathrm{kg}$ & $4.61+01$ & $4.15 \mathrm{E}+01$ & $4.33 \mathrm{E}+01$ & $3.78 \mathrm{E}+01$ & $4.22 \mathrm{E}+01$ & $3.76 \mathrm{E}+01$ & $3.95 \mathrm{E}+01$ & $3.47 \mathrm{E}+01$ \\
\hline Particulates, $<10 \mathrm{um}$ & $\mathrm{kg}$ & $2.83 \mathrm{E}+00$ & $2.55 \mathrm{E}+00$ & $2.66 \mathrm{E}+00$ & $2.32 \mathrm{E}+00$ & $2.59 \mathrm{E}+00$ & $2.31 \mathrm{E}+00$ & $2.43 \mathrm{E}+00$ & $2.13 \mathrm{E}+00$ \\
\hline Particulates, $<2.5$ um & $\mathrm{kg}$ & $8.25 \mathrm{E}+01$ & $7.43 \mathrm{E}+01$ & $7.75 \mathrm{E}+01$ & $6.76 \mathrm{E}+01$ & $7.55 \mathrm{E}+01$ & $6.73 \mathrm{E}+01$ & $7.08 \mathrm{E}+01$ & $6.21 \mathrm{E}+01$ \\
\hline $\mathrm{SO}_{2}$ & $\mathrm{~kg}$ & $1.59 \mathrm{E}+01$ & $1.43 \mathrm{E}+01$ & $1.49 \mathrm{E}+01$ & $1.30 \mathrm{E}+01$ & $1.46 \mathrm{E}+01$ & $1.30 \mathrm{E}+01$ & $1.36 \mathrm{E}+01$ & $1.20 \mathrm{E}+01$ \\
\hline $\mathrm{Zn}$ & $\mathrm{kg}$ & $1.55 \mathrm{E}-02$ & $1.39 \mathrm{E}-02$ & $1.45 \mathrm{E}-02$ & $1.27 \mathrm{E}-02$ & $1.42 \mathrm{E}-02$ & $1.26 \mathrm{E}-02$ & $1.33 \mathrm{E}-02$ & $1.17 \mathrm{E}-02$ \\
\hline
\end{tabular}


Table 2 (continued)

\begin{tabular}{|c|c|c|c|c|c|c|c|c|c|}
\hline Environmental loads & Unit & SS & I & II & III & IV & $\mathrm{V}$ & VI & VII \\
\hline \multicolumn{10}{|l|}{ Emissions to water } \\
\hline Fipronil & $\mathrm{g}$ & $5.47 \mathrm{E}-02$ & $4.92 \mathrm{E}--02$ & $5.14 \mathrm{E}-02$ & $4.48 \mathrm{E}-02$ & $5.01 \mathrm{E}-02$ & $4.46 \mathrm{E}-02$ & $4.69 \mathrm{E}-02$ & $4.12 \mathrm{E}-02$ \\
\hline $\mathrm{PO}_{4}{ }^{3-}$ & $\mathrm{g}$ & $8.67 \mathrm{E}+01$ & $7.80 \mathrm{E}+01$ & $8.15 \mathrm{E}+01$ & $7.11 \mathrm{E}+01$ & $7.94 \mathrm{E}+01$ & $7.06 \mathrm{E}+01$ & $7.45 \mathrm{E}+01$ & $6.54 \mathrm{E}+01$ \\
\hline $\mathrm{P}$ & $\mathrm{g}$ & $1.09 \mathrm{E}+00$ & $9.84 \mathrm{E}-01$ & $1.03 \mathrm{E}+00$ & $8.96 \mathrm{E}-01$ & $1.00 \mathrm{E}+00$ & $8.91 \mathrm{E}-01$ & $9.38 \mathrm{E}-01$ & $8.23 \mathrm{E}-01$ \\
\hline \multicolumn{10}{|l|}{ Emissions to soil } \\
\hline $\mathrm{Cd}$ & $\mathrm{g}$ & $1.10 \mathrm{E}-01$ & $9.94 \mathrm{E}-02$ & $1.04 \mathrm{E}-01$ & $9.05 \mathrm{E}-02$ & $1.01 \mathrm{E}-01$ & $9.00 \mathrm{E}-02$ & $9.47 \mathrm{E}-02$ & $8.32 \mathrm{E}-02$ \\
\hline Carbofuran & $\mathrm{g}$ & $3.77 \mathrm{E}+01$ & $3.40 \mathrm{E}+01$ & $3.54 \mathrm{E}+01$ & $3.09 \mathrm{E}+01$ & $3.45 \mathrm{E}+01$ & $3.08 \mathrm{E}+01$ & $3.24 \mathrm{E}+01$ & $2.84 \mathrm{E}+01$ \\
\hline Diuron & $\mathrm{g}$ & $8.77 \mathrm{E}+00$ & $7.89 \mathrm{E}+00$ & $8.23 \mathrm{E}+00$ & $7.19 \mathrm{E}+00$ & $8.02 \mathrm{E}+00$ & $7.15 \mathrm{E}+00$ & $7.52 \mathrm{E}+00$ & $6.60 \mathrm{E}+00$ \\
\hline Fipronil & $\mathrm{g}$ & $3.59 \mathrm{E}+00$ & $3.23 \mathrm{E}+00$ & $3.37 \mathrm{E}+00$ & $2.94 \mathrm{E}+00$ & $3.29 \mathrm{E}+00$ & $2.93 \mathrm{E}+00$ & $3.08 \mathrm{E}+00$ & $2.71 \mathrm{E}+00$ \\
\hline
\end{tabular}

From a more specific perspective, it is observed that $56 \%$ of the contributions for the category of climate change (CC) are regarding to emissions of dinitrogen oxide $\left(\mathrm{N}_{2} \mathrm{O}\right)$. About $98 \%$ of it occurs in the "sugarcane production" unit process because of activities of burning straw, nitrogen fertilizer oxidation, vinasse and filter cake disposal, as well as waste biomass left on the field, and diesel combustion from agricultural machinery. A parcel of $25.1 \%$ of the impact for the same category can be attributed to carbon dioxide $\left(\mathrm{CO}_{2}\right)$ emitted because of land transformation. Considering the model of expansion of sugarcane for the state of Sao Paulo proposed by Macedo et al (2008), the progress of this cultivation in the region will occur in $80 \%$ on pasture areas, in $19 \%$ on other annual crops, and in $1 \%$ on Brazilian savannah along the period 2009-2010. $\mathrm{CO}_{2}$ emissions derived from land transformation were thus attributed to suppression of vegetation cover from these areas. It should also highlight that $12.8 \%$ of $\mathrm{CO}_{2}$ emissions are from fossil origin, as a consequence of application of urea and lime to soil in order to adjust the cultivation conditions, in the transport of raw materials, and an intermediate process such as farm machinery. Finally, biogenic methane $\left(\mathrm{CH}_{4}\right)$ emitted from straw burning represents $1.3 \%$ of CC impacts.

The most significant contributions as the terrestrial acidification (TA) are associated with emissions of sulfur oxides $\left(\mathrm{SO}_{\mathrm{x}}\right), 71.1 \%$, and ammonia $\left(\mathrm{NH}_{3}\right), 23.9 \%$. Diesel combustion from cultivation, harvesting, and transportation emits $95 \%$ of the total amount of $\mathrm{SO}_{\mathrm{x}}$. Redox (reduction-oxidation) reactions that occur with nitrogenous fertilizers-urea, monoamonium nitrate phosphate, and diamonium nitrate phosphate (MAP and DAP) — which remain in the soil and that are exposed to anaerobic atmosphere represent about $99 \%$ of the $\mathrm{NH}_{3}$ emitted in the "sugarcane production".

Freshwater eutrophication (FEu) displays a defined contribution profile. Phosphate $\left(\mathrm{PO}_{4}{ }^{3-}\right)$ releases in water represent $95.5 \%$ of the environmental burden associated with the category. This contribution is mainly due to losses that occur during production of single superphosphate (SSP) $-4.42 \mathrm{~kg}$ / $\mathrm{t}$ - a phosphate fertilizer regularly used for sugarcane cultivation at the Sao Paulo state.

Human toxicity (HT) occurred from various contributions, all of them associated with the sugarcane cultivation. The

Table 3 Environmental performance profiles for scenarios (delivery of 1.0 MWh of electricity to the grid)

\begin{tabular}{|c|c|c|c|c|c|c|c|c|c|}
\hline \multirow[t]{2}{*}{ Impact category } & \multirow[t]{2}{*}{ Unit } & \multicolumn{8}{|c|}{ Case scenarios } \\
\hline & & SS & I & II & III & IV & V & VI & VII \\
\hline $\mathrm{CC}$ & $\mathrm{kg} \mathrm{CO}_{2}$ eq & $1.17 \mathrm{E}+03$ & $1.05 \mathrm{E}+03$ & $1.10 \mathrm{E}+03$ & $9.60 \mathrm{E}+02$ & $1.07 \mathrm{E}+03$ & $9.55 \mathrm{E}+02$ & $1.00 \mathrm{E}+03$ & $8.82 \mathrm{E}+02$ \\
\hline $\mathrm{TA}$ & $\mathrm{kg} \mathrm{SO}_{2}$ eq & $2.24 \mathrm{E}+01$ & $2.01 \mathrm{E}+01$ & $2.10 \mathrm{E}+01$ & $1.83 \mathrm{E}+01$ & $2.05 \mathrm{E}+01$ & $1.82 \mathrm{E}+01$ & $1.92 \mathrm{E}+01$ & $1.69 \mathrm{E}+01$ \\
\hline $\mathrm{FEu}$ & $\mathrm{kg} \mathrm{P}_{\text {eq }}$ & $2.54 \mathrm{E}-02$ & $2.29 \mathrm{E}-02$ & $2.39 \mathrm{E}-02$ & $2.09 \mathrm{E}-02$ & $2.33 \mathrm{E}-02$ & $2.07 \mathrm{E}-02$ & $2.19 \mathrm{E}-02$ & $1.92 \mathrm{E}-02$ \\
\hline HT & $\mathrm{kg} 1,4-\mathrm{DB}$ eq & $4.71 \mathrm{E}+01$ & $4.23 \mathrm{E}+01$ & $4.42 \mathrm{E}+01$ & $3.86 \mathrm{E}+01$ & $4.31 \mathrm{E}+01$ & $3.83 \mathrm{E}+01$ & $4,04 \mathrm{E}+01$ & $3.54 \mathrm{E}+01$ \\
\hline POF & kg NMVOC & $5.47 \mathrm{E}+01$ & $4.92 \mathrm{E}+01$ & $5.13 \mathrm{E}+01$ & $4.48 \mathrm{E}+01$ & $5.00 \mathrm{E}+01$ & $4.46 \mathrm{E}+01$ & $4.69 \mathrm{E}+01$ & $4.12 \mathrm{E}+01$ \\
\hline PMF & $\mathrm{kg} \mathrm{PM}_{10}$ eq & $8.97 \mathrm{E}+01$ & $8.07 \mathrm{E}+01$ & $8.42 \mathrm{E}+01$ & $7.35 \mathrm{E}+01$ & $8.21 \mathrm{E}+01$ & $7.31 \mathrm{E}+01$ & $7.69 \mathrm{E}+01$ & $6.75 \mathrm{E}+01$ \\
\hline TEc & $\mathrm{kg} 1,4-\mathrm{DB}$ eq & $3.43 \mathrm{E}+00$ & $3.08 \mathrm{E}+00$ & $3.22 \mathrm{E}+00$ & $2.81 \mathrm{E}+00$ & $3.13 \mathrm{E}+00$ & $2.79 \mathrm{E}+00$ & $2.94 \mathrm{E}+00$ & $2.58 \mathrm{E}+00$ \\
\hline FEc & $\mathrm{kg} 1,4-\mathrm{DB}$ eq & $1.41 \mathrm{E}+00$ & $1.27 \mathrm{E}+00$ & $1.32 \mathrm{E}+00$ & $1.16 \mathrm{E}+00$ & $1.29 \mathrm{E}+00$ & $1.15 \mathrm{E}+00$ & $1.21 \mathrm{E}+00$ & $1.06 \mathrm{E}+00$ \\
\hline ALO & $\mathrm{m}^{2} \mathrm{a}$ & $8.03 \mathrm{E}+02$ & $7.22 \mathrm{E}+02$ & $7.53 \mathrm{E}+02$ & $6.58 \mathrm{E}+02$ & $7.35 \mathrm{E}+02$ & $6.54 \mathrm{E}+02$ & $6.89 \mathrm{E}+02$ & $6.04 \mathrm{E}+02$ \\
\hline NLT & $\mathrm{m}^{2}$ & $5.21 \mathrm{E}-02$ & $4.68 \mathrm{E}-02$ & $4.89 \mathrm{E}-02$ & $4.26 \mathrm{E}-02$ & $4.76 \mathrm{E}-02$ & $4.24 \mathrm{E}-02$ & $4.46 \mathrm{E}-02$ & $3.92 \mathrm{E}-02$ \\
\hline WD & $\mathrm{m}^{3}$ & $1.43 \mathrm{E}+01$ & $1.26 \mathrm{E}+01$ & $1.35 \mathrm{E}+01$ & $1.14 \mathrm{E}+01$ & $1.29 \mathrm{E}+01$ & $1.11 \mathrm{E}+01$ & $1.21 \mathrm{E}+01$ & $1.03 \mathrm{E}+01$ \\
\hline FD & $\mathrm{kg}$ oil $_{\mathrm{eq}}$ & $2.38 \mathrm{E}-04$ & $2.15 \mathrm{E}-04$ & $2.24 \mathrm{E}-04$ & $1.95 \mathrm{E}-04$ & $2.18 \mathrm{E}-04$ & $1.94 \mathrm{E}-04$ & $2.05 \mathrm{E}-04$ & $1.80 \mathrm{E}-04$ \\
\hline
\end{tabular}




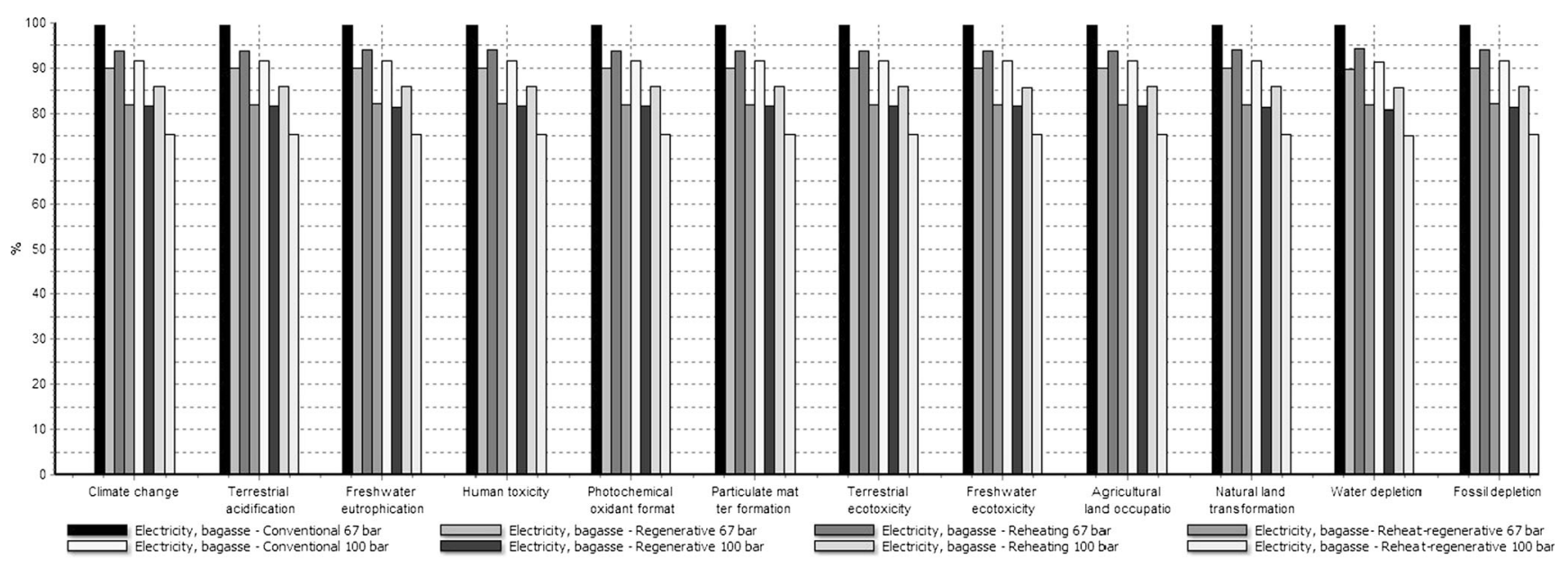

Fig. 10 Comparing alternative scenarios in terms of LCIA by method ReCiPe midpoint (H) V 1.08

stand out is, in this case, the emission of cadmium $(\mathrm{Cd})$ and zinc $(\mathrm{Zn})$ in the air (respectively, 12.4 and $16.7 \%$ of contributions) $\mathrm{Cd}$ to soil (22.3\%), and phosphorous to water $(21.6 \%)$. Diesel combustion for cultivation and harvesting represents more than $94 \%$ of the metal releases in the air. Losses of $\mathrm{Cd}$ to soil can be attributed to phosphate fertilizer application. The presence of $\mathrm{P}$ in the water originates from the production of growth regulators $(67.1 \%)$ and glyphosate $(20.5 \%)$ for plague control in the sugarcane cultivation. Glyphosate is an organophosphorus compound obtained from phosphorus tri- and pentachloride- $\mathrm{PCl}_{3}$ and $\mathrm{PCl}_{5}$. Its production contributes with water losses of $10.7 \mathrm{~kg} \mathrm{P} / \mathrm{t}$ (Green 1987). Growth regulators are employed as pesticides to the sugarcane cultivation in Brazil even if this class of compounds does not actually kill any organisms. As in glyphosate, the growth regulators are also obtained from phosphorus chlorides $(0.186 \mathrm{~kg} / \mathrm{kg})$, and its production imposes the losses of about $95 \mathrm{~kg} \mathrm{P/t}$ (Lucas and Vall 1999).

The burning of sugarcane (straw and leaves) to interrupt the process of saccharification or even biomass for land clearing between successive crops is still a recurrent practice in the state of Sao Paulo. Both processes occur under low-or even virtually nonexistent-excess oxygen. In these conditions, nonmethane volatile organic compounds-NMVOC - and fossil carbon monoxide ( $\mathrm{CO}$ ) are produced by incomplete combustion. These environmental loads represent respectively 84.3 and $6.9 \%$ of the contribution for photochemical oxidant formation (POF).

The same activities, in association with incomplete diesel combustion in obsolete agricultural machinery, justify releases of both $\mathrm{SO}_{\mathrm{x}}$ and particulate matter with specific diameters $<$ $2.5 \mu \mathrm{m}$ and $<10 \mu \mathrm{m}$ into the air. These effects represent respectively $3.6,92$ and $3.2 \%$ of the contribution in terms of particulate matter formation (PMF).

Emission of particles with $<2.5 \mu \mathrm{m}$ occur predominantly at "sugarcane production" (99.4\%). Moreover, atmospheric releases of PM $<10 \mu \mathrm{m}$ arises mainly from burning of bagasse in cogeneration (65.8\%). The remaining $34.2 \%$ proceed from burning of straw in the field. Data presented in Sousa and Macedo (2010) indicate average emissions of $2.77 \mathrm{~kg} \mathrm{SO}_{\mathrm{x}}$ per ton of sugarcane due to the diesel combustion and, once again, to the burning of straw.

The emission to soil of carbofuran (with a contribution of $55.3 \%$ ) fipronil $(8.1 \%)$, and diuron $(7.5 \%)$, active ingredients used for plague control represent, accounts for the main agents in terms of terrestrial ecotoxicity (TEc). To these, the emission to the air of cooper $(\mathrm{Cu})$ from diesel combustion can still be added, which represents $25.1 \%$ of the total amount attributed to the same impact category. Freshwater ecotoxicity (FEc) follows a similar profile. To this case, losses of carbofuran to soil contribute $40.1 \%$ of the total impact. It is followed by releases of fipronil $(14.8 \%)$ and diuron $(7.2 \%)$, both to soil. The emission of $\mathrm{P}$ to water and $\mathrm{Cu}$ in air-in which contributions are 8.5 and $8.1 \%$-may also be highlighted as a significant contribution. As mentioned before, for the case of HT, contributions associated to P emission in water come from the production of growth regulators $(67.2 \%)$ and glyphosate $(20.5 \%)$.

For agricultural land occupation (ALO), $99.6 \%$ of the total contribution calculated for each of the scenarios corresponds to occupation of arable land without irrigation. This result is consistent with the characteristics of extensive cultivation of sugarcane practiced in the state of Sao Paulo for which that classification of land use is quite usual (Sousa and Macedo 2010).

The results in terms of natural land transformation (NLT) can be divided into two categories: indirect and direct effects. Indirect effects represent $75.4 \%$ of total contributions for the category and refer mainly to crude oil circulation $(4.2 \%)$ and natural gas $(1.3 \%)$, which occur by pipelines, installed onshore; flood areas to form dams in hydroelectric power plants (3.4\%); and onshore drilling wells for crude oil exploration $(82.6 \%)$.

Contributions to NLT category regarding hydropower are based on data provided by the National Petroleum, Natural 
Gas and Biofuels Agency (ANP) in which the contribution of this mode to the national energy matrix corresponded to $81.4 \%$ (ANP 2012). Land transformation due to the drilling of oil wells is because Brazil imported in 2011 about $16 \%$ of crude oil from countries like Nigeria, Algeria, Iraq, Saudi Arabia, and Libya, where the extraction of this natural resource occurs on land (ANP 2011). The direct effects are due to the aforementioned expansion of cultivation of cane sugar over the Brazilian savannah.

Water depletion (WD) is concentrated in $90.4 \%$ of the water consumption pumped mainly from rivers for the production of tap water in order to generate steam in the cogeneration system. To this total, consumption - not greater than $1.5 \%$-relative to irrigation water to crops of sugarcane can also be added.

Finally, the contributions of the product system for the purpose of fossil depletion (FD) may also be considered negligible. These focus mainly on the consumption of crude oil (87.8\%), from which, diesel to drive farm machinery and transport vehicles and natural gas (about $2.17 \%$ ) originates from it - for preparation of synthetic nitrogen fertilizers like urea, MAP, and DAP.

\section{Conclusions}

Reheating and regeneration concepts were found to be considerably effective in improving the energy efficiency of cogeneration systems by burning sugarcane bagasse. The results of this study confirmed the expectation that the sugar/alcohol sector can increase the amount of electricity delivered to the national grid using the same amount of natural resources and as a result increase revenue.

Alternatives for improving the Rankine cycle also reduced environmental impacts based on the standard analysis of all examined environmental impacts. The study also verified that any improvement in the sustainable use of natural resources is related to the introduction of more efficient practices for cogeneration systems.

The analysis performed by LCA revealed that the main environmental impacts associated to the delivery of $1.0 \mathrm{MWh}$ of electricity to the national grid from cogeneration of sugarcane bagasse appeared along the agricultural production stages. The inclusion of the environmental variable in the evaluation of alternative technologies for improving energy efficiency of the same system brought a different perception for analysis. Through this approach, it was possible to note that the implementation of effective process optimization, even if it was restricted to only one stage of the life cycle, can result in systemic reductions of the negative effects on the environment provided by an anthropic action. For the case in specific, this finding does not exempt the pursuit of technologies, practices, and more sustainable behaviors on the part of decision makers that comprise the sugarcane sector in Brazil. Prior to this, the conclusions signal that the exercise of Life Cycle Thinking should be stimulated within the industry in order to deliver business value.

Open Access This article is distributed under the terms of the Creative Commons Attribution License which permits any use, distribution, and reproduction in any medium, provided the original author(s) and the source are credited.

\section{References}

ANP - National Petroleum, Natural Gas and Biofuels Agency (2011) Brazilian statistical yearbook of oil, natural gas and biofuels. Rio de Janeiro, p 282

ANP - National Petroleum, Natural Gas and Biofuels Agency (2012) Brazilian Statistical Yearbook of oil, natural gas and biofuels. Rio de Janeiro. p 280

Bocci E, Di Carlo A, Marcelo D (2009) Power plant perspectives for sugarcane mills. Energy 34:689-698

Cavalett O, Chagas M, Seabra J, Bonomi A (2013) Comparative LCA of ethanol versus gasoline in Brazil using different LCIA methods. Int J Life Cycle Assess 18:647-658

CGEE (Center for Strategic Studies and Management) (2008) Bioethanol sugarcane: energy for sustainable development. BNDES, Rio de Janeiro

Dias M, Modesto M, Ensinas A, Nebra S, Filho R, Rossel C (2011) Improving bioethanol production from sugarcane: evaluation of distillation, thermal integration and cogeneration systems. Energy 36(6):3691-3703

Gaudreault C, Sanson R, Stuart P (2010) Energy decision making in a pulp and paper mill: selection of LCA system boundary. Int J Life Cycle Assess 15:198-211

Gil M, Moya A, Domíngues E (2013) Life cycle assessment of the cogeneration processes in the Cuban sugar industry. J Clean Prod 41:222-231

Goedkoop M, Heijungs R, Huijbregts M, De Schryver A, Struijs J (2013) Description of the ReCiPe methodology for life cycle impact assessment. In: ReCiPe main report (revised 13 May 2012). http:// www.lcia-recipe.net. Accessed 7 Sept 2012

Gonzáles-García S, Iribarren D, Susmozas A, Dufour J, Murphy R (2012) Life cycle assessment of two alternative bioenergy systems involving Salix spp. biomass: bioethanol production and power generation. Appl Energy 95:111-122

Green, M. (1987) Energy in pesticide manufacture, distribution and use. In: Helsel ZR (ed.) Energy in plant nutrition and pest control, Vol. 7. Elsevier, Amsterdam, ISBN 0-444-42753-8, pp. 165-177

ISO 14040 (2006a) International Organization for Standardization, Environmental management-life cycle assessment-principles and framework. Geneva. p 21

ISO 14044 (2006b) International Organization for Standardization, Environmental management-life cycle assessment — requirements and guidelines. Geneva, 52p

Lucas S, Vall MP (1999) Pesticides in the European Union. Agriculture, Environment, Rural Development-Facts and Figures. European Communities. http://europa.eu.int/comm/agriculture/envir/report/ en/pest_en/report_en.htm

Luo L, Voet E, Huppes G (2008) Life cycle assessment and life cycle costing of bioethanol from sugarcane in Brazil. Renew Sustain Energy Rev 13:1613-1619

Macedo I, Seabra J, Silva J (2008) Greenhouse gases emissions in the production and use of ethanol from sugarcane in Brazil. The 
2005/2006 averages and prediction for 2020. Biomass 7. Energy 32: 582-595

MAPA (Ministry of Agriculture, Livestock and Supply) (2011) Secretariat and bioenergy production, sugar and ethanol in Brazil. Harvest 2010-2011. Industry statistics, Brasília

MME (Ministry of Mines and Energy) (2011) Review Brazilian energy 2010. MME, Brasília

Moran J, Shapiro N (2008) Fundamentals of engineering thermodynamics, 6th edn. John Wiley \& Sons, New York

Nguyen T, Gheewala S (2008) Life cycle assessment of fuel ethanol from cane molasses in Thailand. Int J Life Cycle Assess 13:301-311
Ometto A, Hauschild M, Roma W (2009) Lifecycle assessment of fuel ethanol from sugarcane in Brazil. Int J Life Cycle Assess 14:236 247

Renouf M, Pagan R, Wegener M (2011) Life cycle assessment of Australian sugarcane products. Int J Life Cycle Assess 16:125137

Sousa E, Macedo I (Org.) (2010) Ethanol and bioelectricity: sugarcane in the future energy mix. Luc Communication Project, São Paulo

Tina G, Passarello G (2011) Short-term scheduling of industrial cogeneration systems for annual revenue maximization. Energy 42:46-56 